\title{
Effect of borax application on young coconut palms
}

\author{
P.G. Kamalakshiamma ${ }^{1}$, M. Shanavas ${ }^{1}$, D. Prema ${ }^{2}$ and Jacob Mathew ${ }^{1}$
}

\begin{abstract}
There is increasing incidence of boron deficiency in coconut palms in the root (wilt) affected tract in the southern districts of Kerala, India. An earlier survey in this tract indicated that $19-25 \%$ of the palms had boron deficiency symptoms. The symptoms manifested due to boron deficiency in coconut palms include malformations in leaves as well as in the nuts resulting in stunted growth and low productivity. A field experiment was conducted at Central Plantation Crops Research Institute, Kayamkulam to study the effect of different doses of boron on deficiency symptoms and the nutrition of coconut seedlings. The results revealed that the seedlings which had boron deficiency symptoms showed recovery with the

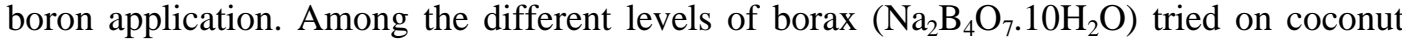
seedlings, application of $300 \mathrm{~g}$ borax per seedling per year in two equal splits was found effective to achieve recovery and to improve the growth of the young seedlings. The seedlings treated with borax showed improvement in growth parameters such as girth at collar, annual leaf production and total functional leaves and boron content in leaf tissues.
\end{abstract}

\footnotetext{
${ }^{1}$ Central Plantation Crops Research Institute, Regional Station, Krishnapuram.P.O, Kayangulam, Kerala690 533, India.

${ }^{2}$ Central Marine Fisheries Institute, Cochin, Kerala, India.
} 


\section{Introduction}

Boron is an essential micronutrient for plants. In nature boron is moderately rare and occurs principally as borates of calcium and sodium. It occurs in soils in the form of tourmaline. Its availability is maximum within the $\mathrm{pH}$ range 5-7. Boron is less available above the $\mathrm{pH}$ of 7.5. Excessive liming accentuates boron deficiency in recent years the boron deficiency has become common in coconut palm which causes malformations of various types and shapes in the leaf as well as in the nuts resulting in stunted growth and low productivity. A deficiency symptom varies from palm to palm and all the symptoms may not be expressed on a single palm. It was reported that $12 \%$ of the coconut palms in Kerala were affected by boron deficiency symptoms (Pillai et al., 1983). But the survey conducted during 1997 revealed that 1926 per cent of the palms were affected by this malady (Kamalakshiamma et al., 2001). It adversely affects the growth and health of the palms resulting in delayed flowering, in certain severe conditions causes death of the seedlings. With the above background, a field experiment was carried out to investigate the effect of borax application in ameliorating the deficiency symptoms and on the nutrition of coconut seedlings.

\section{Materials and methods}

A field experiment was conducted to study the role of boron in coconut nutrition at CPCRI (RS), Kayangulam, Kerala with 5 treatments on three year old seedlings of west coast tall cultivar showing various symptoms of boron deficiency in RBD (Table 1). The experimental field represented endemic root (wilt) affected area in sandy loam soil with low fertility status and acidic $(\mathrm{pH} 5.5)$ in nature. The mechanical composition of soil has 86 per cent sand, 7.8 per cent clay and 2 per cent silt. The nutrient status of the soil was poor with 4 and 28 ppm available $\mathrm{N}$ and $\mathrm{K}$ respectively. The soil was rich in available $\mathrm{P}$ (48 ppm). The common boron deficiency symptoms in a seedling (before flowering) are fasciation (Fig. 1), hooking (Fig.
2), hardness, reduction in the leaf size (Fig. 3), cracking in the petiole/midrib (Fig. 4), whipping at the tip of the leaf (Fig. 5) etc. In order to quantify the deficiency symptoms of boron in the seedlings all these symptoms were taken into account for indexing the intensity of symptom expression. Similar type of indexing was done for quantifying the intensity of root (wilt) disease in coconut (George and Radha, 1973). Based on multiple regression analysis, the severity of the disease symptoms was quantified using the relationship Intensity $=(11.7(\mathrm{~F}+\mathrm{L})+$ $(2.5 \mathrm{x} \mathrm{H})+7.5(\mathrm{R}+\mathrm{C}+\mathrm{W})) / \mathrm{l}$, where for fasciation $(\mathrm{F})$, hardness $(\mathrm{L})$, hooking $(\mathrm{H})$ each leaf was scored in a 0 to 3 scale where 0 represent the absence of symptoms and 1,2,3 stand for $1 / 3,2 / 3$ and full. In the case of reduction of leaf size (R) and cracking in the petiole/midrib (C) and whipping at the tip of the leaf $(\mathrm{W})$, the grade points assigned were 0 and 1 , showing the absence or presence of the symptoms and 1 stands for number of leaves on the crown.

All the experimental palms were indexed according to the above formula. The mean values of the intensity of deficiency at the start of the experiment ranged from 41.8 to 45.1. Growth parameters of the seedlings like girth at collar, height, number of frond production per year and number of functional leaves on the crown were recorded.

Table 1. Details of treatment (dose/palm/year)

\begin{tabular}{|l|l|}
\hline \multicolumn{1}{|c|}{ Treatment } & \multicolumn{1}{c|}{ Details } \\
\hline T1 & $100 \mathrm{~g}$ Borax \\
\hline $\mathrm{T} 2$ & $300 \mathrm{~g}$ Borax \\
\hline $\mathrm{T} 3$ & $500 \mathrm{~g}$ Borax \\
\hline $\mathrm{T} 4$ & $700 \mathrm{~g}$ Borax \\
\hline T5 & Control \\
\hline Replication & 3 \\
\hline Design & RBD \\
\hline Soil & Sandy loam \\
\hline No of palms per plot & 6 \\
\hline Age of seedlings & 3 years \\
\hline
\end{tabular}




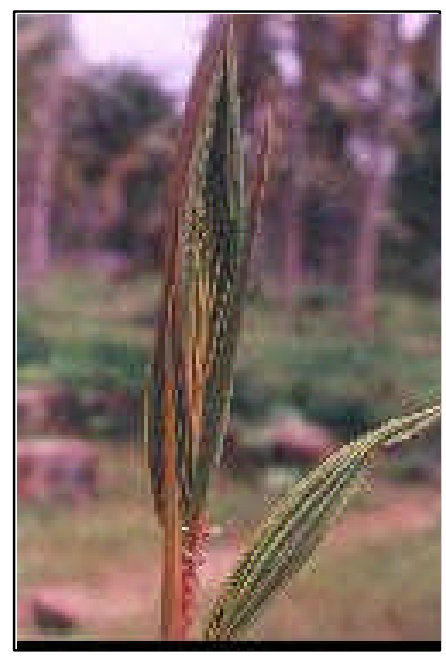

Fig. 1. Fasciation of leaves

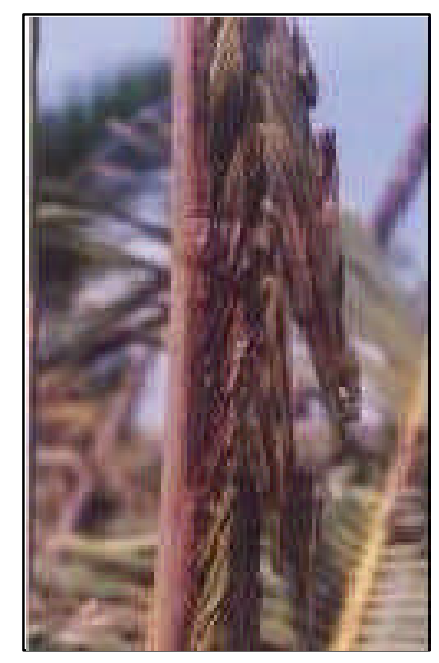

Fig. 2. Hooking of leaves

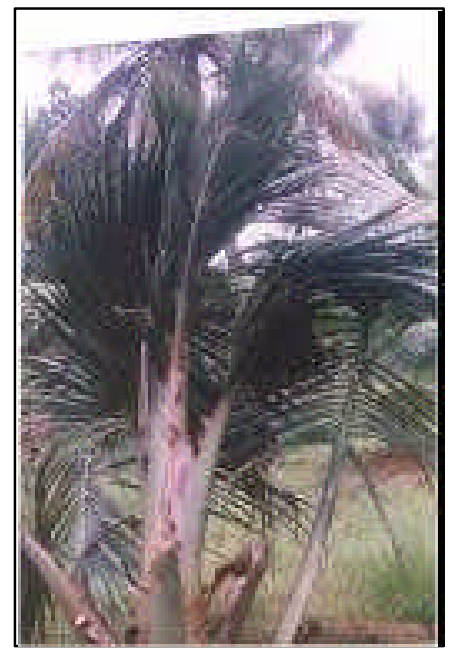

Fig. 3. Reduction of leaf size

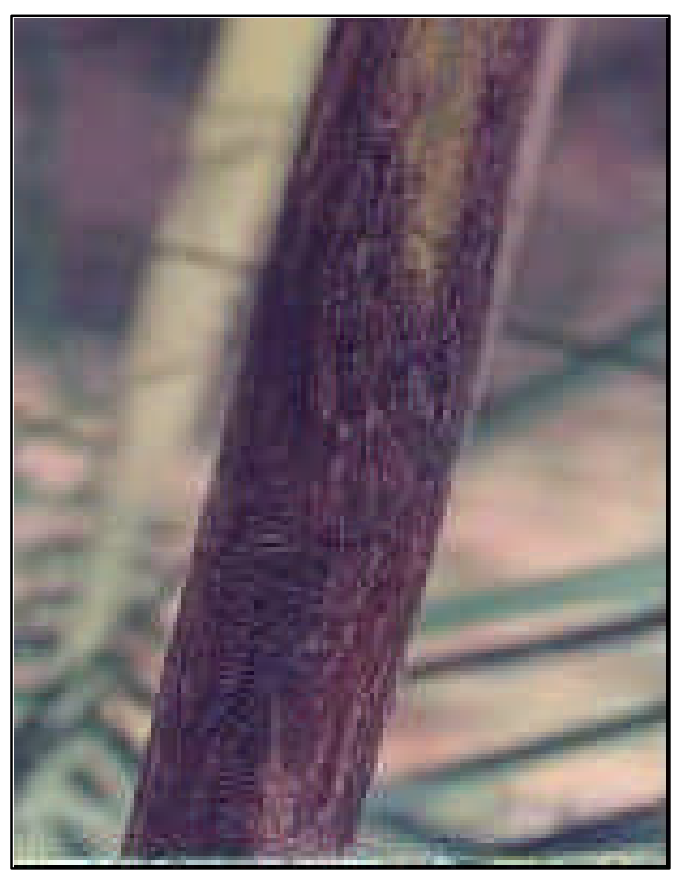

Fig. 4. Cracking in the petiole

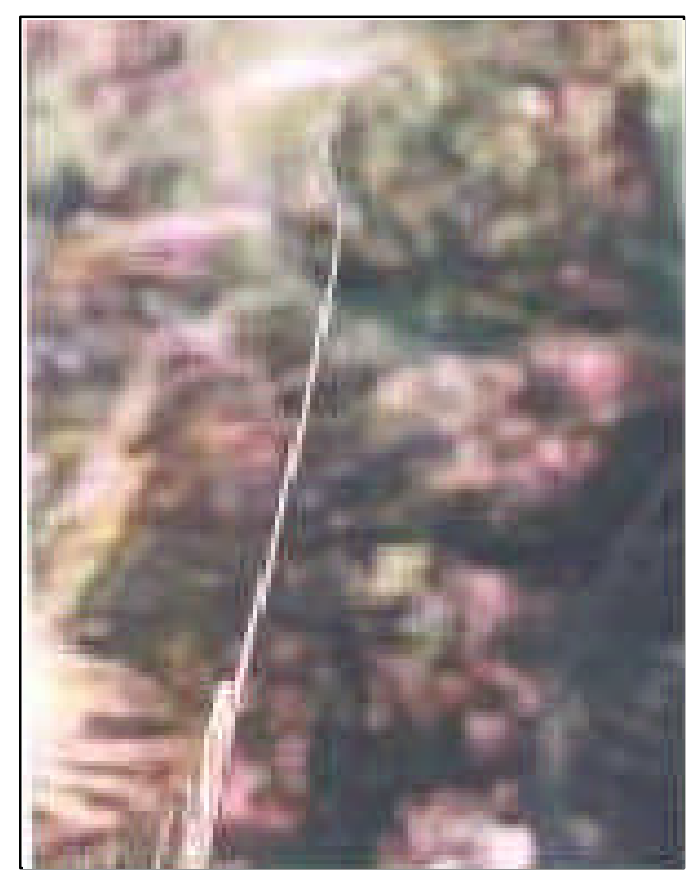

Fig. 5. Whipping at the tip of the leaf 
Indexing of the palms for the improvement of the seedlings was recorded at every six months. The palms were supplied with borax in two split doses along with the scheduled dose of N, P, K, and $\mathrm{Mg}$ fertilizers. Soil and leaf samples were collected before and after the treatment and analyzed. For the estimations of nutrients standard methods (Jackson, 1973) were followed.

\section{Results and discussion}

\section{Vegetative growth}

The field experiment was conducted from 1997 to 2000 and the growth parameters of coconut seedlings were recorded each year.

\section{Girth at collar}

The initial values for the girth at color of the seedlings in different treatments did not show any significant variation. Borax application did not influence collar girth during 1998 whereas during 1999 and 2000 significant response was observed for the treatments T2, T3 and T4 compared to control. Even though application of different levels of borax to the seedlings increased the girth significantly, the highest percentage of increase (343) was observed in the treatment T2 (Table 2).

\section{Height}

The values for the height of the seedlings in different treatments (Table 3) did not show any significant variation. However, the borax treated palms showed increase in height (159 to 173 per cent) when compared to control (135). This is in agreement with the earlier findings of Margate $e t$ al. (1979).

\section{Frond production rate}

The rate of frond production is depicted in the Table 4. Application of borax had significant influence on frond production throughout the experimental period. Numbers of leaves produced were higher in borax treated palms when compared to control.

\section{Functional leaves on the crown}

The data shows significant increase in the functional leaves on the crown of palms treated with boron at different levels (Table 5). The percentage increase in the number of functional leaves due to borax application ranged from 24 to 65 per cent whereas only 4 per cent increase was observed in control.

\section{Nutrient status of leaf and soil}

The results of nutrient content of leaf and soil are presented in Tables 6-9. The data showed that $\mathrm{N}, \mathrm{P}, \mathrm{K}, \mathrm{B}, \mathrm{Fe}$ and $\mathrm{Cu}$ were significantly increased due to the application of fertilisers. The boron status of the leaf increased significantly when compared to control, but there was not much difference between treatments. The nutrient status of the soil $(0-50$ cm depth) viz. $\mathrm{P}, \mathrm{K}, \mathrm{Mg}, \mathrm{Zn}, \mathrm{Cu}, \mathrm{Mn}, \mathrm{Fe}$ and $\mathrm{B}$ also significantly increased after the treatment.

The effect of treatments on the intensity of deficiency symptoms is given in Fig. 6. All the palms treated with borax showed tremendous improvement in the condition of the palms as indicated by the gradual decrease in the disease intensity. However, palms receiving $100 \mathrm{~g}$ of borax could not recovered by the end of 18 months, whereas palms receiving higher doses of borax had recovered from the deficiency symptoms by the end of 18 months (Figs. $7 \& 8$ ). Among the borax doses, there was no additional effect for the higher doses $(500 \& 700 \mathrm{~g})$ over the lower dose $(300 \mathrm{~g})$ in reducing the symptoms and also in remission of the disorders of the seedlings within a particular period of time. Application of $300 \mathrm{~g}$ borax could be taken as an economic dose and recommended for the deficiency correction. This dose can be applied in two or more split doses. If there is change in the visual symptoms within six months of application no more addition is required. More over the higher doses cause scorching, necrosis and yellowing symptoms in the seedlings. 
Table 2. Girth at collar $(\mathrm{cm})$ of coconut as influenced by borax application

\begin{tabular}{|l|c|c|c|c|c|}
\hline \multicolumn{1}{|c|}{ Treat/Year } & 1997 & 1998 & 1999 & 2000 & \% Increase over 3 years \\
\hline T1 & 14.7 & 16.8 & 30.9 & 43.4 & 195 \\
T2 & 14.8 & 23.5 & 36.9 & 65.6 & 343 \\
T3 & 16.9 & 22.3 & 33.9 & 68.3 & 304 \\
T4 & 17.3 & 22.2 & 34.2 & 68.4 & 295 \\
T5-control & 13.8 & 18.0 & 30.6 & 39.7 & 188 \\
CD p=0.5\% & NS & NS & 4.9 & 3.2 & \\
\hline
\end{tabular}

Table 3. Height $(\mathrm{cm})$ of coconut as influenced by borax application

\begin{tabular}{|l|c|c|c|c|c|}
\hline \multicolumn{1}{|c|}{ Treat/Year } & 1997 & 1998 & 1999 & 2000 & \% Increase over 3 years \\
\hline T1 & 132 & 148 & 245 & 343 & 159 \\
T2 & 136 & 175 & 309 & 363 & 167 \\
T3 & 136 & 177 & 313 & 372 & 173 \\
T4 & 136 & 179 & 319 & 368 & 171 \\
T5-control & 133 & 172 & 208 & 312 & 135 \\
CD p=0.5\% & NS & NS & NS & NS & \\
\hline
\end{tabular}

Table 4. Annual leaf production per palm per year as influenced by borax application

\begin{tabular}{|l|c|c|c|c|c|}
\hline \multicolumn{1}{|c|}{ Treat/Year } & 1997 & 1998 & 1999 & 2000 & \% Increase over 3 years \\
\hline T1 & 5 & 6 & 6 & 7 & 44 \\
T2 & 5 & 7 & 7 & 7 & 58 \\
T3 & 4 & 8 & 7 & 7 & 55 \\
T4 & 4 & 7 & 7 & 7 & 58 \\
T5-control & 4 & 4 & 5 & 6 & 38 \\
CD p-0.5\% & NS & 0.7 & 1.2 & 0.6 & \\
\hline
\end{tabular}


Table 5. Total functional leaves on the crown as influenced by borax application

\begin{tabular}{|l|c|c|c|c|c|}
\hline \multicolumn{1}{|c|}{ Treat/Year } & 1997 & 1998 & 1999 & 2000 & \% Increase over 3 years \\
\hline T1 & 10 & 11 & 10 & 12 & 24 \\
T2 & 9 & 12 & 13 & 15 & 64 \\
T3 & 10 & 13 & 15 & 17 & 65 \\
T4 & 10 & 13 & 14 & 17 & 65 \\
T5-control & 10 & 10 & 9 & 10 & 4 \\
CD p=0.5\% & NS & 1.1 & 1.4 & 1.4 & \\
\hline
\end{tabular}

Table 6. Effect of borax application on leaf N, P, K, Ca and Mg content

\begin{tabular}{|l|c|c|c|c|c|c|c|c|c|c|}
\hline \multirow{2}{*}{ Treatments } & \multicolumn{2}{|c|}{ N\% } & \multicolumn{2}{c|}{$\mathrm{P}(\%)$} & \multicolumn{2}{c|}{$\mathrm{K}(\%)$} & \multicolumn{2}{c|}{ Ca (meq/100) } & \multicolumn{2}{c|}{$\mathrm{Mg}(\mathrm{meq} / 100)$} \\
\cline { 2 - 11 } & Pre & Post & Pre & Post & Pre & Post & Pre & Post & Pre & Post \\
\hline T1 & 1.08 & 1.78 & 0.22 & 0.34 & 0.90 & 1.60 & 0.34 & 0.22 & 0.23 & 0.33 \\
T2 & 0.90 & 1.80 & 0.20 & 0.35 & 0.89 & 1.70 & 0.36 & 0.24 & 0.22 & 0.34 \\
T3 & 1.17 & 1.80 & 0.23 & 0.38 & 0.88 & 1.70 & 0.36 & 0.24 & 0.22 & 0.34 \\
T4 & 1.10 & 1.82 & 0.21 & 0.38 & 1.10 & 1.80 & 0.36 & 0.22 & 0.25 & 0.35 \\
T5 & 0.92 & 1.43 & 0.24 & 0.34 & 1.10 & 1.50 & 0.34 & 0.34 & 0.25 & 0.32 \\
\hline $\begin{array}{l}\text { CD (p=5\%) } \\
\text { between pre \& } \\
\text { post }\end{array}$ & \multicolumn{10}{|c|}{0.069} \\
\hline
\end{tabular}

Table 7. Effect of borax application on leaf $\mathrm{Zn}, \mathrm{Cu}, \mathrm{Mn}, \mathrm{Fe}$ and $\mathrm{B}$ content

\begin{tabular}{|c|c|c|c|c|c|c|c|c|c|c|}
\hline \multirow{2}{*}{ Treatments } & \multicolumn{2}{|c|}{$\mathrm{Zn}(\mathrm{ppm})$} & \multicolumn{2}{|c|}{$\mathrm{Cu}(\mathrm{ppm})$} & \multicolumn{2}{|c|}{$\mathrm{Mn}(\mathrm{ppm})$} & \multicolumn{2}{|c|}{$\mathrm{Fe}(\mathrm{ppm})$} & \multicolumn{2}{|c|}{ B (ppm) } \\
\hline & Pre & Pos & Pre & Post & Pre & Post & Pre & Post & Pre & Post \\
\hline $\mathrm{T} 1$ & 10.67 & 12.20 & 5.33 & 5.80 & 10.53 & 11.50 & 20.10 & 21.93 & 5.17 & 9.40 \\
\hline $\mathrm{T} 2$ & 9.90 & 11.00 & 5.50 & 6.13 & 11.57 & 12.47 & 20.53 & 23.27 & 3.73 & 10.07 \\
\hline T3 & 11.17 & 12.13 & 3.80 & 4.27 & 10.53 & 12.53 & 20.67 & 22.27 & 3.43 & 10.03 \\
\hline $\mathrm{T} 4$ & 10.03 & 10.40 & 4.00 & 5.17 & 9.60 & 12.53 & 20.27 & 23.00 & 4.20 & 9.93 \\
\hline T5 & 10.73 & 11.33 & 3.87 & 5.27 & 11.17 & 11.87 & 22.03 & 23.53 & 3.73 & 4.50 \\
\hline $\begin{array}{l}\mathrm{CD}(\mathrm{p}=5 \%) \\
\text { between } \\
\text { pre \& post }\end{array}$ & \multicolumn{2}{|c|}{$\mathrm{N}$} & \multicolumn{2}{|c|}{0.410} & \multicolumn{2}{|c|}{ NS } & \multicolumn{2}{|c|}{1.522} & \multicolumn{2}{|c|}{0.517} \\
\hline
\end{tabular}


Table 8. Effect of borax application on soil organic carbon, available $P, K$ and exchangeable $\mathrm{Ca}$ and $\mathrm{Mg}(\mathbf{0 - 5 0} \mathrm{cm})$

\begin{tabular}{|c|c|c|c|c|c|c|c|c|c|c|}
\hline \multirow{2}{*}{ Treatments } & \multicolumn{2}{|c|}{ Org C\% } & \multicolumn{2}{|c|}{$\mathrm{P}(\mathrm{ppm})$} & \multicolumn{2}{|c|}{$\mathrm{K}(\mathrm{ppm})$} & \multicolumn{2}{|c|}{$\mathrm{Ca}(\mathrm{meq} / 100 \mathrm{~g})$} & \multicolumn{2}{|c|}{$\begin{array}{c}\mathrm{Mg} \\
(\mathrm{meq} / 100 \mathrm{~g})\end{array}$} \\
\hline & Pre & Post & Pre & Post & Pre & Post & Pre & Post & Pre & Post \\
\hline $\mathrm{T} 1$ & 0.17 & 0.19 & 22.33 & 34.33 & 21.30 & 61.77 & 0.51 & 0.50 & 0.22 & 0.28 \\
\hline $\mathrm{T} 2$ & 0.17 & 0.20 & 22.60 & 41.00 & 21.40 & 63.70 & 0.51 & 0.50 & 0.22 & 0.28 \\
\hline $\mathrm{T} 3$ & 0.16 & 0.20 & 22.97 & 42.77 & 21.90 & 64.07 & 0.52 & 0.52 & 0.23 & 0.28 \\
\hline $\mathrm{T} 4$ & 0.17 & 0.19 & 22.17 & 43.40 & 22.27 & 63.37 & 0.51 & 0.50 & 0.23 & 0.28 \\
\hline $\mathrm{T} 5$ & 0.17 & 0.19 & 21.57 & 31.60 & 23.07 & 31.97 & 0.54 & 0.49 & 0.22 & 0.26 \\
\hline $\begin{array}{l}\mathrm{CD}(\mathrm{p}=5 \%) \\
\text { between pre } \\
\& \text { post }\end{array}$ & \multicolumn{2}{|c|}{0.005} & \multicolumn{2}{|c|}{1.057} & \multicolumn{2}{|c|}{0.736} & \multicolumn{2}{|c|}{ NS } & \multicolumn{2}{|c|}{0.013} \\
\hline
\end{tabular}

Table 9. Effect of borax application on soil, available $\mathrm{Zn}, \mathrm{Cu}, \mathrm{Mn} \mathrm{Fe}$ and $\mathrm{B}(0-50 \mathrm{~cm})$

\begin{tabular}{|l|c|c|c|c|c|c|c|c|c|c|}
\hline \multirow{2}{*}{ Treatments } & \multicolumn{2}{|c|}{$\mathrm{Zn}(\mathrm{ppm})$} & \multicolumn{2}{c|}{$\mathrm{Cu}(\mathrm{ppm})$} & \multicolumn{2}{c|}{ Mn $(\mathrm{ppm})$} & \multicolumn{2}{c|}{ Fe $(\mathrm{ppm})$} & \multicolumn{2}{c|}{$\mathrm{B}(\mathrm{ppm})$} \\
\cline { 2 - 12 } & Pre & Post & Pre & Post & Pre & Post & Pre & Post & Pre & Post \\
\hline T1 & 0.62 & 1.46 & 0.80 & 1.40 & 1.35 & 2.31 & 4.83 & 6.17 & 0.01 & 0.34 \\
T2 & 0.62 & 1.53 & 0.82 & 1.73 & 1.38 & 2.40 & 5.00 & 6.70 & 0.01 & 0.36 \\
T3 & 0.63 & 1.50 & 0.74 & 1.73 & 1.35 & 2.47 & 5.10 & 6.87 & 0.01 & 0.39 \\
T4 & 0.64 & 1.48 & 0.78 & 1.70 & 1.37 & 2.43 & 5.07 & 6.87 & 0.02 & 0.29 \\
T5 & 0.62 & 1.50 & 0.72 & 1.37 & 1.36 & 2.07 & 5.07 & 5.00 & 0.01 & 0.001 \\
\hline CD (p=5\%) & \multicolumn{10}{|c|}{0.034} \\
between Pre & 0.034 post
\end{tabular}




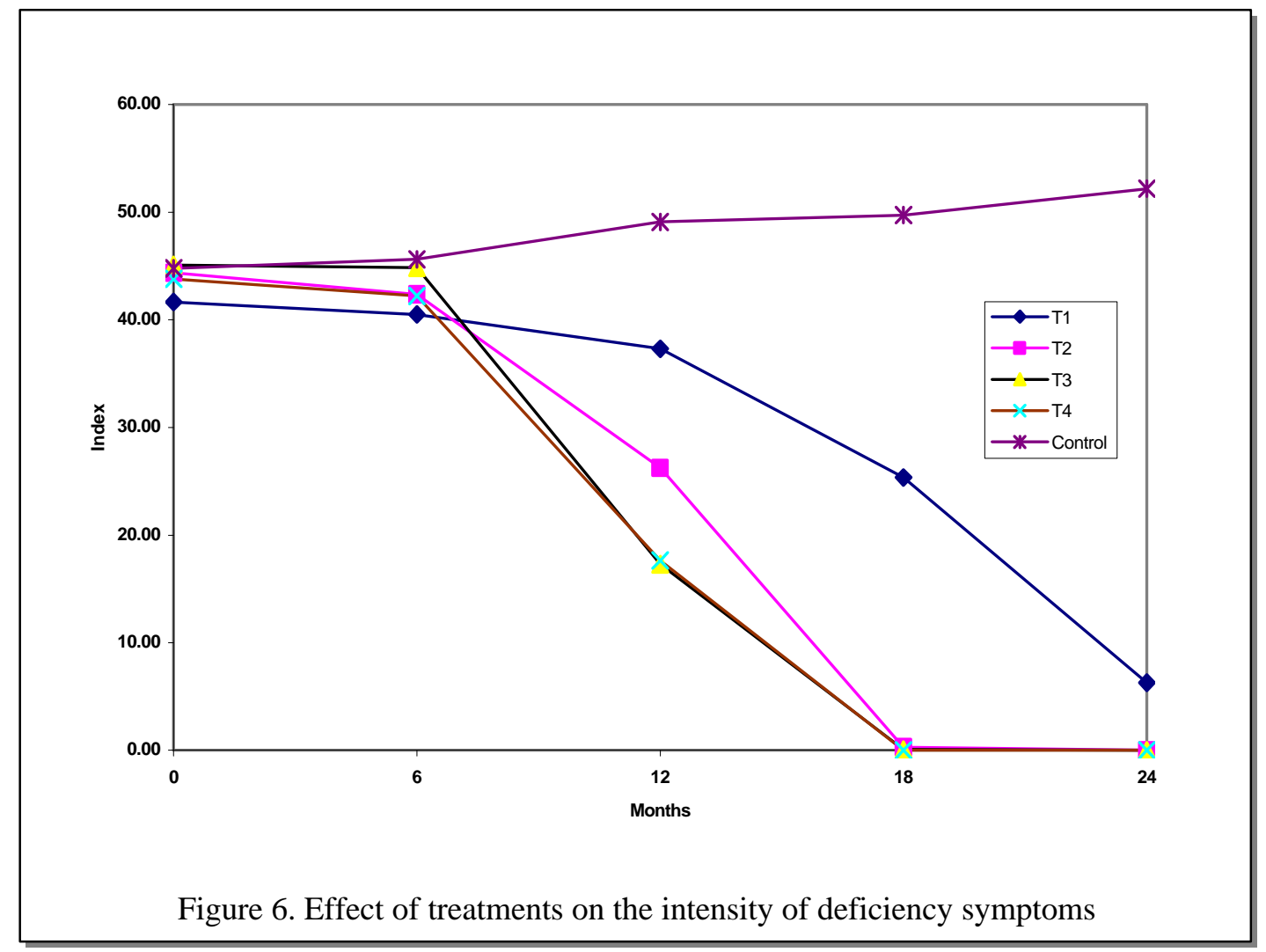

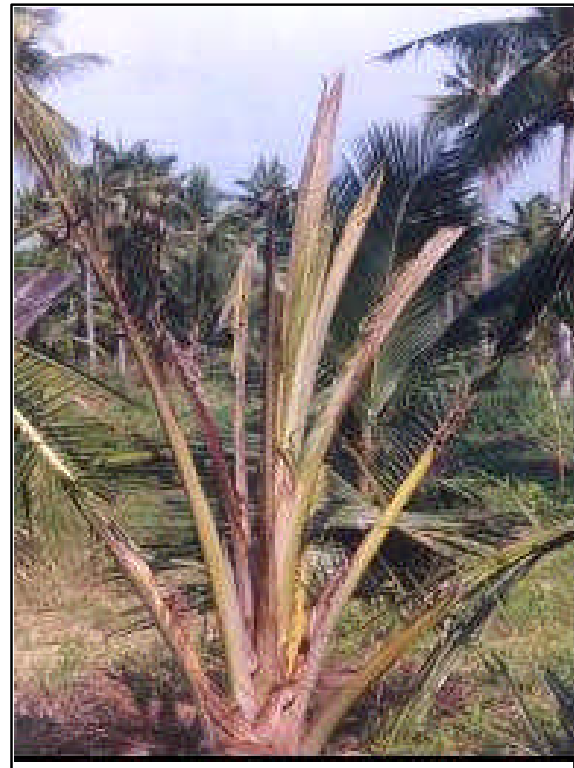

Fig. 7. Boron deficient Palm

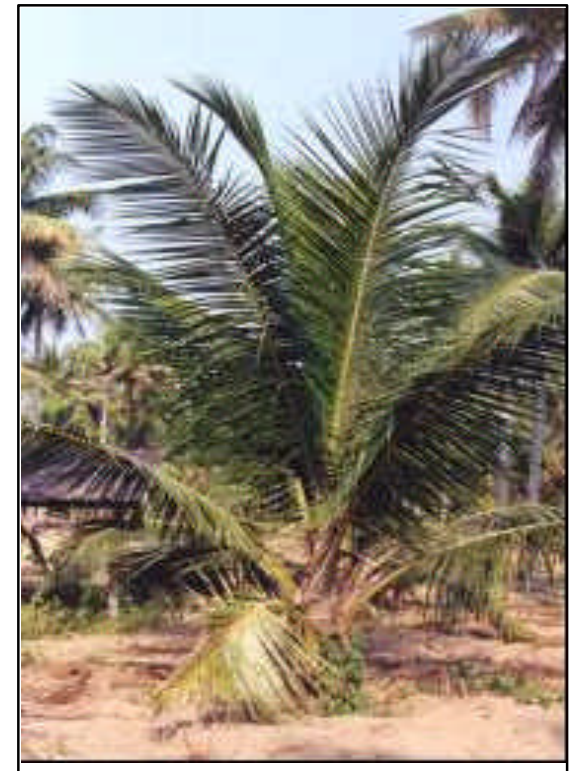

Fig. 8. Same palm after 18 months of boron application 
Similar results were also reported by Brunin and Coomans (1973). In seedlings the leaf emerging after six months of borax application was found to be free from any malformation. But a malformed leaf due to boron deficiency cannot be brought back to normal shape. Irrigation must be followed after application of borax during summer months.

\section{Conclusion}

From the study it was found that the boron deficiency could be completely rectified by borax application. Among different levels of borax $\left(\mathrm{Na}_{2} \mathrm{~B}_{4} \mathrm{O}_{7} \cdot 10 \mathrm{H}_{2} \mathrm{O}\right)$ tried on palms exhibiting deficiency symptoms, application of $300 \mathrm{~g}$ borax per palm per year in two equal splits was found effective to achieve recovery and as well as to increase the growth of young palms. Higher levels of borax (500 g or more) had no additional effect on performance of the seedlings as it caused scorching of the leaves of the palm.

\section{Acknowledgement}

The authors are thankful to Dr. H.P. Maheswarappa, Sr. Scientinst, Agronomy Division, CPCRI (RS), Kayangulam for the critical perusal of the manuscript.

\section{References}

Brunin, C. and Coomans, P. 1973. Boron deficiency in young coconut in Ivory Coast. Oleagineux 28(5): 229-234.

Cecil, S.R. and Pillai, N.G. 1978. Role of boron in coconut nutrition. Indian Cocon. J. 9: 1- 3.

George, M.V. and Radha, K. 1973. Computation of disease index of root (wilt) disease of coconut. Indian J. Agric. Sci. 43(4): 366370.

Jackson, M.L. 1973. Soil Chemical Analysis. Prentice Hall of Plant. India (Pvt) Ltd. New Delhi.
Kamalakshiamma, P.G., Prema, D. and Shanavas, M. 2001. Boron deficiency in coconut (Cocos nucifera L). Diagnosis and Correction. Technical Bulletin No. 40. Published by V. Rajagopal., Director, Central Plantation Crops Research Institute and Edited by H.H. Khan, H.P. Maheswarappa and P. Anitha Kumari.

Kamalakshiamma, P.G. 2001. Role of Boron in Coconut Nutrition. Final Report, 106 pp.

Margate, R.Z, Magat, S.S. and Abad, R.G. 1979. Boron requirement of hybrid coconut seedlings grown in an island coconut soil of Davao. Philippine $J$. Cocon. Stud. 4(3): 6-14.

Pillai, N.G., Kamaladevi, C.B., Wahid, P.A. and Nambiar, C.K.B. 1983. Available micronutrient status of major soil types under coconut in healthy and root (wilt) affected tracts of Kerala, India, pp. 144151. In: Coconut Research and Development. Nayar, N.M. (Ed.). Wiley Eastern, New Delhi. 